\title{
Mycelial growth and sporulation of Apoharknessia eucalyptorum on different culture media
}

\author{
Alexandre Techy de Almeida Garrett ${ }^{\oplus}$, Álvaro Figueredo dos Santos ${ }^{2} \oplus$, Afonso Figueiredo Filho' ${ }^{1}$,

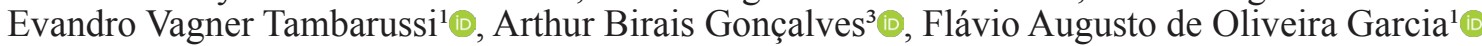

${ }^{I}$ Postgraduate Program in Forestry Sciences, Department of Forest Engineering, Universidade Estadual do Centro-Oeste, BR 153, Km 7, 84500-000, Irati, PR, Brazil; ${ }^{2}$ Empresa Brasileira de Pesquisa Agropecuária, Estrada da Ribeira, Km 111, Cx.Postal 319, Guaraituba, 83411-000, Colombo, PR, Brazil; ${ }^{3}$ Department of Forest Engineering, Universidade Estadual do Centro-Oeste, BR 153, Km 7, 84500-000, Irati, PR, Brazil; Corresponding author: Alexandre Techy de Almeida Garrett (garrettflorestal@gmail.com) Data de chegada: 10/07/2018. Aceito para publicação em: 08/02/2019.

$10.1590 / 0100-5405 / 207327$

\section{ABSTRACT}

Garrett, A.T.A.; Santos, A.F.; Figueiredo Filho, A.; Tambarussi, E.V.; Gonçalves, A.B.; Garcia, F.A.O. Mycelial growth and sporulation of Apoharknessia eucalyptorum on different culture media. Summa Phytopathologica, v.45, n.3, p.272-278, 2019.

Apoharknessia eucalyptorum was first described in 2017 and identified on leaves of Eucalyptus dunnii in Southern Brazil. However, information about in vitro cultivation for complementary studies is lacking. In the present study, leaves of $E$. dunnii were inoculated to demonstrate the pathogenicity of A. eucalyptorum, and growth and sporulation were evaluated at temperatures of 15,20 , and $25^{\circ} \mathrm{C}$ on four culture media: malt extract agar (MEA); potato dextrose agar (PDA); V8 juice agar (V8); and bean dextrose agar (BEAN), under constant lighting. Apoharknessia eucalyptorum caused leaf blight on the inoculated leaves. The best conditions for mycelial growth were at $25^{\circ} \mathrm{C}$ on PDA, BEAN and MEA. Considering sporulation, optimal conditions were $25^{\circ} \mathrm{C}$ for all tested media and $20^{\circ} \mathrm{C}$ for PDA and BEAN. Colony characteristics changed with temperature; at $15^{\circ} \mathrm{C}$ colonies formed a fluffy mycelium, whereas at $25^{\circ} \mathrm{C}$ mycelium spread across the medium forming dark margins lined by dirty-white mycelium and conidia. The conditions indicated for in vitro growth and sporulation of $A$. eucalyptorum are the culture media MEA, PDA and BEAN at $25^{\circ} \mathrm{C}$

Keywords: colony characteristics; inoculation; temperature.

\section{RESUMO}

Garrett, A.T.A.; Santos, A.F.; Figueiredo Filho, A.; Tambarussi, E.V.; Gonçalves, A.B.; Garcia, F.A.O. Crescimento micelial e esporulação de Apoharknessia eucalyptorum em diferentes meios de cultura. Summa Phytopathologica, v.45, n.3, p.272-278, 2019.

Apoharknessia eucalyptorum foi inicialmente descrita em 2017 e identificada em folhas de Eucalyptus dunnii no Sul do Brasil. No entanto, faltam informações sobre o cultivo in-vitro para estudos complementares. No presente estudo folhas de $E$. dunnii foram inoculadas para demonstrar a patogenicidade de A. eucalyptorum, e o crescimento e esporulação foram avaliados em temperaturas de 15,20 e $25^{\circ} \mathrm{C}$ em quatro meios de cultura: extrato de malte-ágar (MEA), batata dextrose-ágar (PDA), suco V8-ágar (V8) e feijão dextrose-ágar (BEAN), sob luz constante. Apoharknessia eucalyptorum causou manchas foliares nas folhas inoculadas. As melhores condições para o crescimento micelial foram em $25^{\circ} \mathrm{C}$ em PDA, BEAN e MEA. Para a esporulação as melhores condições foram a $25^{\circ} \mathrm{C}$ em todos os meios testados, e também a $20^{\circ} \mathrm{C}$ em PDA e BEAN. As características das colônias mudaram com as temperaturas, em $15^{\circ} \mathrm{C}$ as colônias formaram micélio cotonoso, enquanto que em $25^{\circ} \mathrm{C}$ o micélio cresceu espalhado pelo meio de cultura formando margens escuras limitadas por micélio branco manchado e conídios. As condições indicadas para o crescimento e esporulação in-vitro de A. eucalyptorum são os meios MEA, PDA e BEAN em $25^{\circ} \mathrm{C}$.

Palavras-chave: características de colônia; inoculação; temperatura.

Several pathogens can limit growth or reduce yield of eucalypt seedlings and plantations. In vitro cultivation is a key process in characterizing the size, color, and shape of phytopathogen structures, providing colonies for molecular and host- pathogen interactions studies.

One pathogen that lacks information about in-vitro cultivation is Apoharknessia eucalyptorum Crous \& M.J. Wingfield. The genus Apoharknessia was separated from Harknessia by Lee et al. (18) and proposed due to phylogenetic clustering and hyaline conidia with apical appendage. The genus consists of three species: Apoharknessia insueta (18), Apoharknessia eucalyptorum (6), and Apoharknessia eucalypti (19). Apoharknessia eucalyptorum was isolated from lower crown leaves of Eucalyptus dunnii that were planted in a cold region of Southern Brazil with the occurrence of frosts (GenBank Accession Number MG725682).
Species of the related genus Harknessia $(7,11)$ are dispersed around the world, causing leaf spots and cankers in eucalypts (18). Currently, A. insueta is associated with leaf spots in the United States, Brazil, Colombia, Costa Rica, Cuba, Mauritius, and Zimbabwe (7, 11, 18, 21), while A. eucalyptorum is restricted to Malaysia (6) and Brazil (16).

Harknessia spp., A. insueta, and A. eucalyptorum are eucalypt pathogens $(8,14,16)$ that cause leaf spots, leaf scorch, and cankers $(7,29)$. Harknessia species, some of which occur in Brazil (3), are better studied and considered economically significant as they have been shown to cause damage to plantations $(9,18,23)$. However, some species are limited to specific regions and not aggressive, for example with only a few species occurring in Australia (28). Although these species are better studied, there is still a lack of information about their pathogenicity (7), particularly for Apoharknessia.

To obtain pure in vitro cultures for further studies, microorganisms 
are cultivated on media to promote their growth under laboratory conditions (20). The main nutrients needed for microbiological growth are carbon, nitrogen, phosphorus, sulfur, potassium, magnesium, calcium, and sodium, and each microorganism has different metabolic requirements in terms of nutrients (20). Physical factors must also be considered in promoting the growth of microorganisms, such as temperature, light regime, and $\mathrm{pH}(12,20,26)$.

Harknessia species have been cultured on Malt Extract Agar (MEA) at $25^{\circ} \mathrm{C}$ for five to eight days to characterize the cultures (18), as well as on Potato Dextrose Agar (PDA) (7) and tomato decoction (27). Harknessia spp. are characterized by branched, septate, hyaline to pale brown mycelium usually sporulating in one month (7), while Apoharknessia species sporulate sooner than Harknessia and produce white mycelium $(6,18)$.

Thus, due to the limited information about pathogenicity and in vitro cultivation of $A$. eucalyptorum, this study characterized and evaluated mycelial growth and sporulation of $A$. eucalyptorum on four culture media at three temperatures to determine optimal conditions to cultivate the species.

\section{MATERIAL AND METHODS}

\section{Apoharknessia eucalyptorum isolate}

The isolate of $A$. eucalyptorum was obtained from $E$. dunnii plantations in Northern Santa Catarina State, Brazil. The pathogen was identified on old leaves of the crown, causing irregular or circular leaf spots, with necrotic lesions of light brown color and pycnidia on the lesions. Pycnidia were collected directly from the leaves and deposited on Petri dishes containing Malt Extract Agar (MEA 2\%). After isolation, genomic DNA was extracted based on the CTAB method and using the Quick-DNA ${ }^{\mathrm{TM}}$ Universal Kit (Zymo Research Corp, Irvine, California, USA). Amplification of the internal transcribed spacer 1 - 5.8S - internal transcribed spacer 2 (ITS) region of ribosomal DNA, was used to confirm the isolate identity with the specific primers ITS1 (TCCGTAGGTGAACCTGCGG) and ITS4 (CTCCGCTTATTGATATGCT). The PCR amplicon was sequenced at LGC Genomics GmbH, Germany. The ITS sequence was compared with available sequences in GenBank using BLAST to confirm pathogen identity. The isolate was examined under a microscope to characterize and measure the length of 50 conidia. The monosporic culture of Apoharknessia eucalyptorum APO1 (GENBANK Accession number MG725682) was used in the experiments and deposited in the Laboratório de Patologia Florestal of the Universidade Estadual do Centro-Oeste (UNICENTRO), in Irati, Paraná, Brazil.

\section{Culture media}

Four culture media were tested: Malt Extract Agar (MEA); Potato Dextrose Agar (PDA); V8 juice agar (V8) prepared according to Alfenas and Mafia (2); and Bean dextrose agar (BEAN). The BEAN medium was prepared with $10 \mathrm{~g}$ of powdered beans, $20 \mathrm{~g}$ of dextrose, $20 \mathrm{~g}$ of agar, to $1 \mathrm{~L}$ of sterile water (22). The media were sterilized in an autoclave at $120^{\circ} \mathrm{C}$ for 20 minutes, then $20 \mathrm{~mL}$ was poured onto 90 $\mathrm{mm}$ diameter Petri dishes under sterile conditions.

\section{Experimental design}

The experiment design was completely randomized as a factorial (culture medium $x$ temperature) in a Bio-Oxygen Demand (BOD) incubator with controlled temperature and photoperiod. Petri dishes of all culture media were randomly placed in the BOD incubator, at three temperatures $\left(15,20\right.$, and $\left.25^{\circ} \mathrm{C}\right)$ with constant lighting. Each culture medium had five repetitions (Petri dishes) for each tested temperature.

\section{Evaluation of mycelial growth and sporulation}

One centimeter discs from a sporulated monosporic culture of $A$. eucalyptorum cultured on MEA, were transferred to 90-mm Petri dishes containing each of the tested media. Mycelial growth was measured length-wise, and sporulation was evaluated based on the number of spores per $\mathrm{mL}$ after seven days of incubation. Twenty millimeters of sterile water containing Tween $80(0.05 \%)$ was added to Petri dishes colonized by A. eucalyptorum and then scraped with a brush to count the number of spores per $\mathrm{mL}$. The spore suspension was filtered with cheese cloth and counted in a Neubauer chamber. After diameter growth evaluations, the growth rate (GR) was determined $\left(\mathrm{mm} \mathrm{D}^{-1}\right)$.

\section{Inoculation on leaves}

Pathogenicity of $A$. eucalyptorum was confirmed by inoculating six leaves of $E$. dunnii with a conidial suspension. The conidial suspension was prepared from Petri dishes containing MEA on which A. eucalyptorum was incubated at $25^{\circ} \mathrm{C}$ with a 12 -hour photoperiod for two weeks. After adding $20 \mathrm{~mL}$ of sterilized water, the colony was scraped with a glass rod to remove the conidia and the suspension was filtered with cheese cloth. Conidia concentration of the filtered suspension was determined in a Neubauer chamber and adjusted for a final suspension of $1 \times 10^{6}$ conidia per $\mathrm{ml}$.

Leaves of E. dunnii collected in the field were inoculated with the suspension, avoiding the runoff of the suspension from the leaf surface. Before inoculation, leaves were washed and superficial sterilized under sterile conditions rising the leaves for 30 seconds in ethanol $50 \%$, and in sodium hypochlorite $1.5 \%$ for 30 seconds, washing them in sterile water. The leaves were incubated for one week in 150-mm Petri dishes containing sterile agar-agar medium, at room temperature. After observing the symptoms and signs of the pathogen, conidia masses were collected from the leaves and examined microscopically to compare the morphology with cultures incubated in vitro.

\section{Statistical analysis}

Data on mycelial growth of Apoharknessia eucalyptorum and number of spores per $\mathrm{mL}$ in each medium were submitted to analysis of variance, and the averages compared by Tukey's test at $5 \%(\alpha \leq 0.05)$. Data of mycelial growth was transformed by $\log _{10} X$, and sporulation data was transformed by $\log _{10}(\mathrm{X}+10)$.

\section{RESULTS AND DISCUSSION}

The identification of the isolate was confirmed by BLAST in GenBank, with $99 \%$ identity to an isolate of A. eucalyptorum (Isolate KY979752; Identities $=627 / 631(99 \%), 2$ gaps) obtained from Malaysia on E. pellita, and used by Crous et al. (6) to describe the species. Conidia of the APO1 isolate measured 7 to $12.5 \mu \mathrm{m}$ in length and 4.5 to $7 \mu \mathrm{m}$ in width, with a conical apiculus and a hyaline basal appendage that was tubular, smooth, and thin-walled, with a length of 2.5 to $3.5 \mu \mathrm{m}$ (Figure 1-A and B). One week after inoculation, leaves inoculated with the conidia suspension showed symptoms and conidial masses of A. eucalyptorum (Figure 1-C). The average size of the conidia is in the range described by Crous et al. (6) for the species, showing the conical apiculus and hyaline basal appendage typical of the species. 
Table 1. Average mycelial growth (millimeters) and growth rate of Apoharknessia eucalyptorum at temperatures of 15,20 , and $25^{\circ} \mathrm{C}$ after seven days.

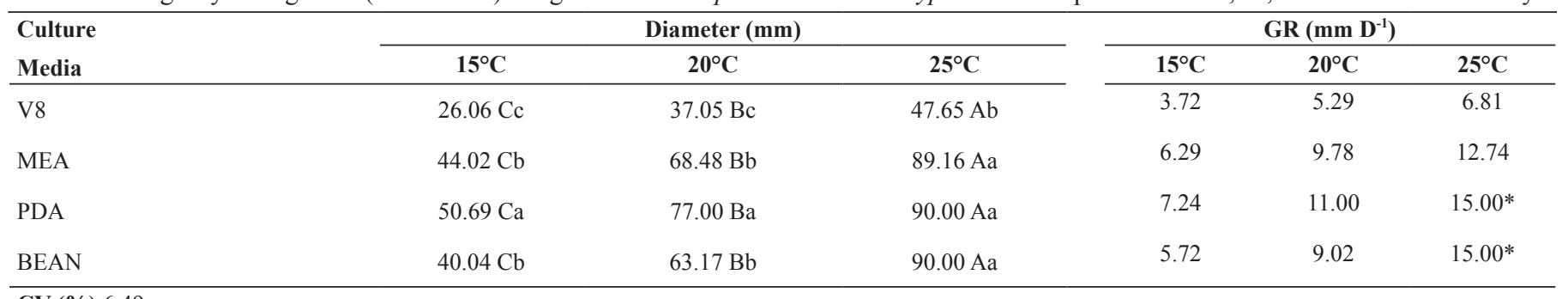

CV (\%) 6.49

Averages followed by the same uppercase letter in a row and lowercase letter in a column do not differ statistically according to Tukey's test ( $\alpha \leq 0.05)$. (CV) Coefficient of variation. $(*)$ Growth Rate (GR) calculated six days after inoculation.

The discussion presented herein is based mainly on the related species of Harknessia and A. insueta, both of which are considered pathogenic. Although pathogenicity studies are important to understand and manage host-pathogen interactions, there are few studies that discuss the ideal conditions for in vitro cultivation.

Although Crous et al. (6) consider that A. eucalyptorum is endophytic, the pathogenic characteristic of the species is shown through the inoculation tests described herein and the previous study by Garrett et al. (16). The symptoms of Harknessia spp. are usually light to dark brown, of a round or irregularly shaped margins or occurring on the leaf edges $(11,21,28)$. Species of Harknessia are also associated with symptoms of tip dieback and leaf scorch on Eucalyptus spp. (7). The symptoms of $A$. eucalyptorum found herein are similar to those described in the literature for Harknessia spp., including conidial masses on the lesions, similar to that observed for H. eucalipty on eucalypt plants (11).

A significant interaction between media and tested temperature was observed ( $p=0.0046)$ for A. eucalyptorum mycelial growth. Mycelial growth increased with an increasing temperature from 15 to $25^{\circ} \mathrm{C}$. Mycelial growth on each medium and at each temperature was greatest on PDA and lowest on V8 medium at 15 and $20^{\circ} \mathrm{C}$. However, mycelial growth at $25^{\circ} \mathrm{C}$ was statistically the same for PDA, BEAN, and MEA (Table 1). In this study, mycelia reached the edge of the Petri dishes on PDA and BEAN within six days.

Growth rate was greater for Harknessia uromycoides at $20^{\circ} \mathrm{C}$ and at $25^{\circ} \mathrm{C}$, while for $\mathrm{H}$. eucalyptorum it was observed at $25^{\circ} \mathrm{C}(10)$, both cultured on MEA. Harknessia ipereneae and H. gibbosa grow better on PDA, and covered Petri dishes in two weeks with fluffy white mycelium $(7,9)$. Another isolate of Harknessia sp. from Venezuela was also cultured on PDA at $25^{\circ} \mathrm{C}$ for 12 days (21). Many Harknessia species have been cultured on MEA, PDA, and Oatmeal agar at $25^{\circ} \mathrm{C}$ (7), while $H$. renispora, has been cultured on a medium based on a tomato or oatmeal decoction (27).

In this study, growth was greater at $25^{\circ} \mathrm{C}$ for all tested media, with the greatest growth rate for MEA, PDA, and BEAN, the latter of which was developed recently for cultivation of Pestalotiopsis spp.

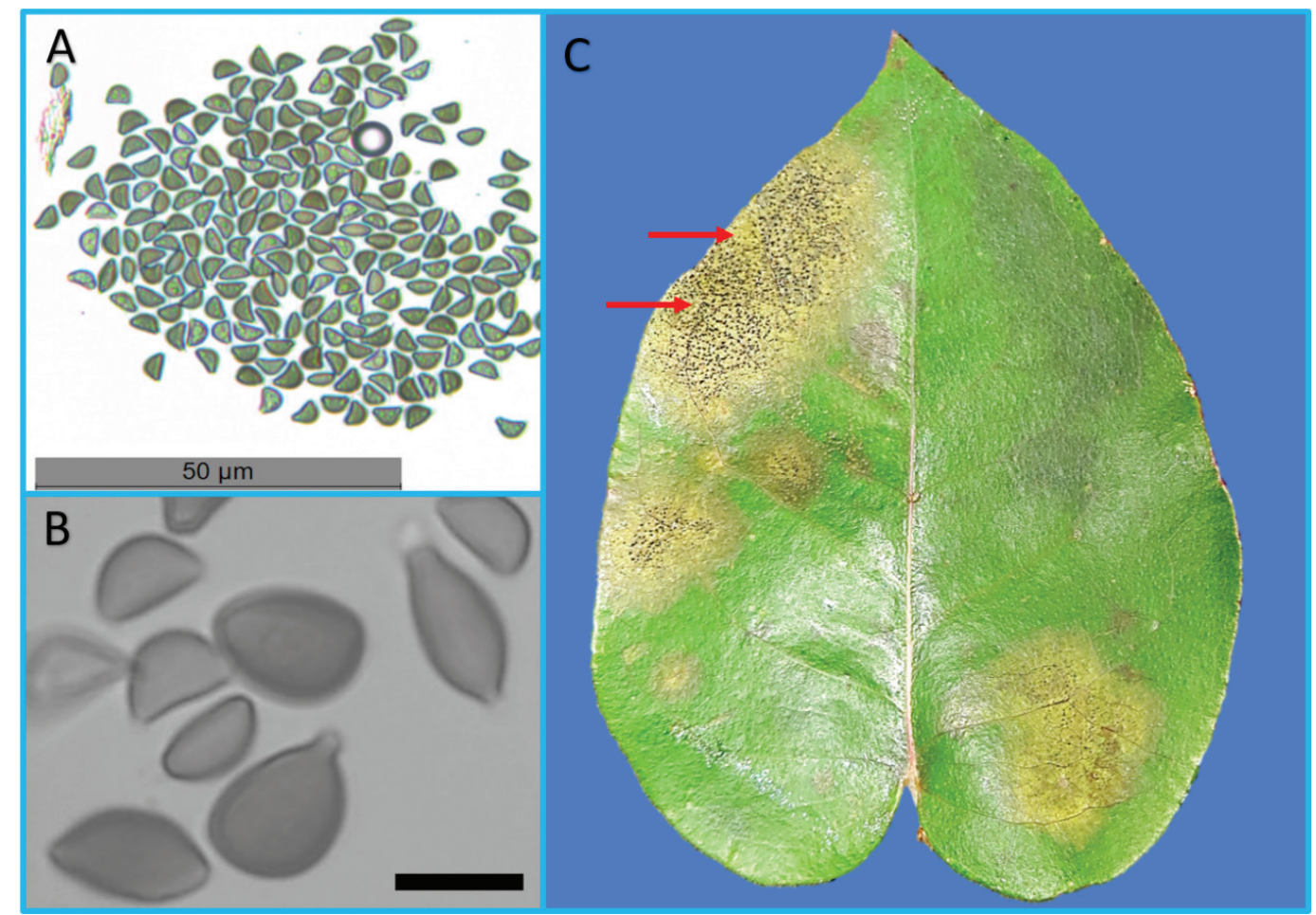

Figure 1. Spores and symptoms of Apoharknessia eucalyptorum on wounded leaf. (A-B) Conidia. (C) Symptoms (brown area) and signs (black dots within brown area highlighted by red arrows) on Eucalyptus dunnii leaf inoculated with conidia suspension. Scale: $10 \mu \mathrm{m}$. Source: The authors. 
Table 2. Average sporulation (conidia $\mathrm{ml}^{-1}$ ) of Apoharknessia eucalyptorum at temperatures of 15,20 , and $25^{\circ} \mathrm{C}$ after seven days.

\begin{tabular}{cccc}
\hline \multirow{2}{*}{ Culture media } & \multicolumn{3}{c}{ TEMPERATURE } \\
\cline { 2 - 4 } & $\mathbf{1 5}^{\circ} \mathbf{C}$ & $\mathbf{2 0}^{\circ} \mathbf{C}$ & $\mathbf{2 5}^{\circ} \mathbf{C}$ \\
\hline \multirow{2}{*}{ V8 } & $0.56 \mathrm{Cc}$ & $2.95 \mathrm{Bb}$ & $11.28 \mathrm{Aa}$ \\
MEA & $1.45 \mathrm{Bb}$ & $2.30 \mathrm{Bb}$ & $10.40 \mathrm{Aa}$ \\
PDA & $2.68 \mathrm{Bab}$ & $15.35 \mathrm{Aa}$ & $9.65 \mathrm{Aa}$ \\
BEAN & $3.28 \mathrm{Ba}$ & $9.65 \mathrm{Aa}$ & $10.28 \mathrm{Aa}$ \\
\hline
\end{tabular}

CV (\%) 53.01

Averages followed by the same uppercase letter in a row and lowercase letter in a column do not differ statistically according to Tukey's test $(\alpha \leq 0.05)$. (CV) Coefficient of variation.
(22). All the culture media tested in this study are natural media with uncertain nutrient contents, particularly in terms of nitrogen and carbon (1). Nevertheless, the use of natural media is suitable due to ease of preparation and reduced cost (5). Moreover, while PDA has been shown to allow growth of different fungi (24), in this study the BEAN medium proved to be suitable for satisfactory growth and sporulation of A. eucalyptorum.

Interaction between medium and temperature was also significant $(p<0.004)$ for sporulation. Similarly to mycelial growth, sporulation of A. eucalyptorum increased as temperature increased. However, sporulation on V8 and MEA showed less conidia per ml than PDA and BEAN media at 15 or $20^{\circ} \mathrm{C}$. Sporulation at 20 and $25^{\circ} \mathrm{C}$ was statistically similar for PDA and $\mathrm{BEAN}$, and at $25^{\circ} \mathrm{C}$ the number of conidia was the same for all tested media (Table 2). Sporulation was observed within

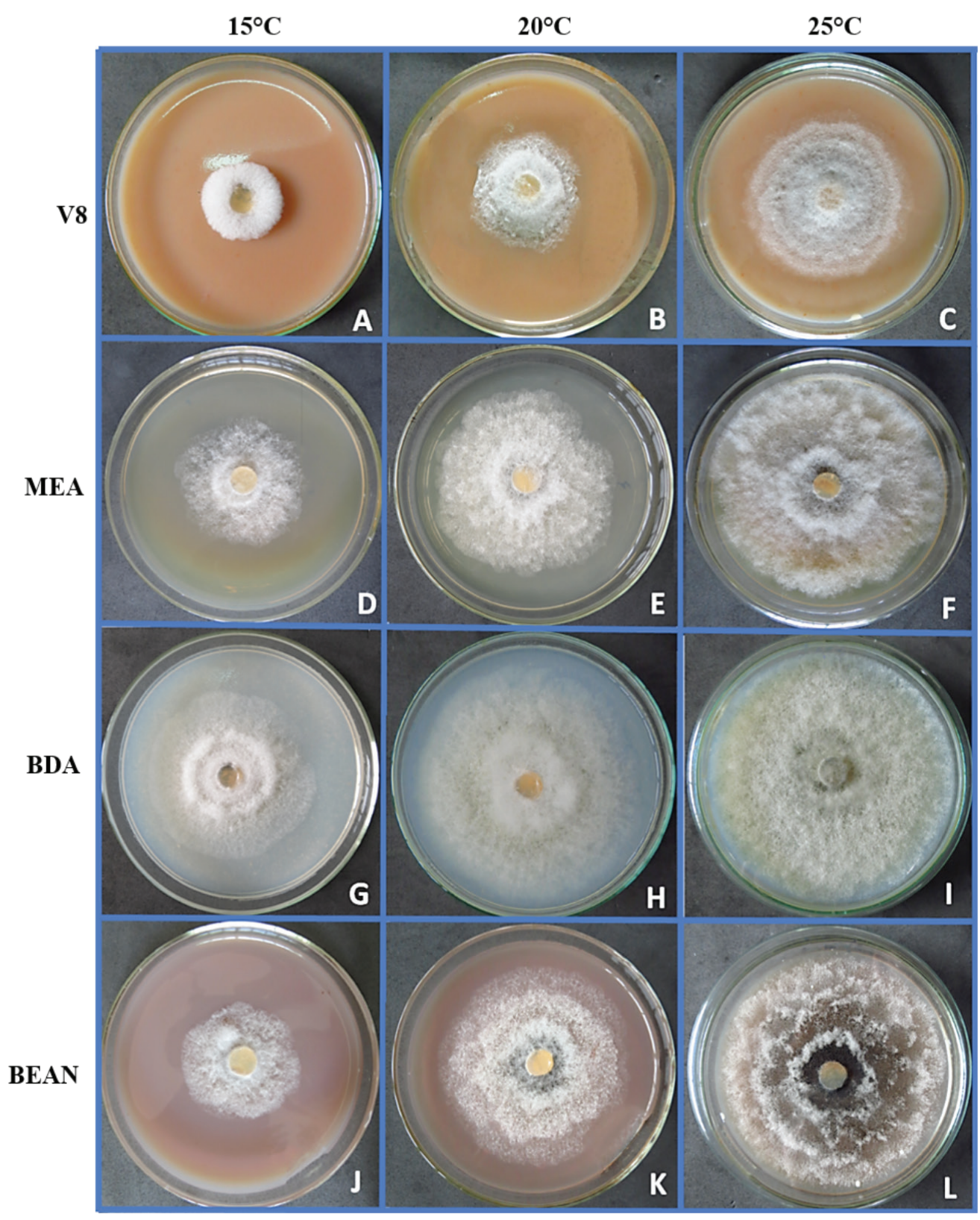

Figure 2. In vitro characteristics of mycelial growth and sporulation of Apoharknessia eucalyptorum. (A-D-G-J) $15^{\circ} \mathrm{C}$; (B-E-H-K) $20^{\circ} \mathrm{C}$; (C-F-I-L) $25^{\circ} \mathrm{C}$; (A, B, and C) V8 medium; (D, E, and F) MEA medium; (G, H, and I) PDA medium; (J, K, and L) BEAN medium. Source: The authors. 


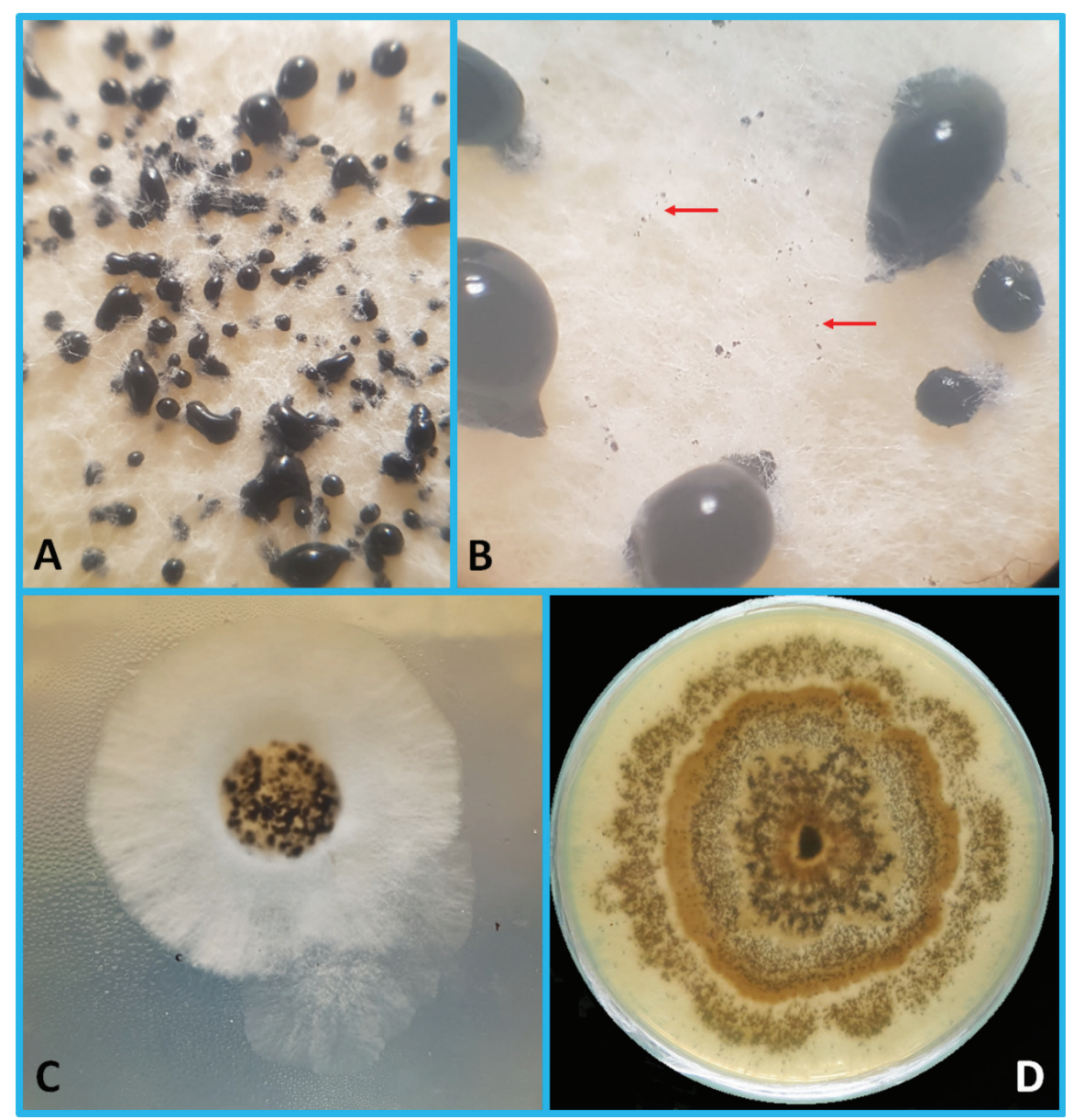

Figure 3. Characteristics of Apoharknessia eucalyptorum on MEA. (A) Viscous sporulation on MEA. (B) Detail of viscous sporulation on MEA and conidia on naked hyphae (arrows). (C) Filamentous mycelia at the beginning of growth on MEA; (D) Reverse side of MEA colonized by $A$. eucalyptorum with olivaceous mycelium, and mycelium and sporulation forming borders on MEA. Source: The authors.

four days for all media.

Production of spores in vitro is important for inoculation (1) and taxonomic studies. Harknessia spp., such as Harknessia eucalyptorum (10), usually sporulate after two weeks (6), while H. hawaiiensis sporulates after one week and other species after two or more weeks (10). Harknessia capensis and H. globispora sporulate in a few days and have white mycelia with margins (18). In comparison, the mycelial growth of $A$. insueta and A. eucalyptorum is faster and sporulation occurs in one week, as described by Lee et al. (18) and Crous et al. (6). Herein, sporulation was observed within four days for all tested media, and diameter reaching $90 \mathrm{~mm}$ within six days at $25^{\circ} \mathrm{C}$. Meanwhile, Crous et al. (6) described growth to $70 \mathrm{~mm}$ in two weeks at $25^{\circ} \mathrm{C}$. This difference in growth could be due to the light regime, since this study was done under constant lighting, which favored mycelial growth on all tested media. Even though sporulation occurred in a few days at $25^{\circ} \mathrm{C}$, mycelial growth on V8 did not reach the full diameter of the Petri dishes $(90 \mathrm{~mm})$. Growth on MEA across the entire dish was observed only after seven days, while it occurred within six days on PDA and BEAN, demonstrating that the tested media are suitable for in vitro cultivation of $A$. eucalyptorum with an intense light regime.

Sporulation in vitro is necessary because the morphology of conidia can help to distinguish species of Harknessia from other fungal species, such $A$. insueta and A. eucalyptorum (10, 13, 15). According to Crous et al. (8), Harknessia species are characterized by stromatic or pycnidial conidiomata producing dark brown conidia with striations and tubular shaped basal appendages. In contrast, Apoharknessia species have brown conidia without striations, but with both basal and apical appendages, and $A$. eucalyptorum has a central guttule in conidia $(6,7,18)$.

Figure 2 shows growth and sporulation characteristics in each tested medium. Mycelial growth and sporulation of A. eucalyptorum increased with increasing temperatures, with growth and sporulation varying for the tested media. Mycelia were white and fluffy at $15^{\circ} \mathrm{C}$, becoming sparse, fine, and growing through the media as temperature increased, with viscous sporulation and conidia on naked hyphae (Figure $3 \mathrm{~A}$ and B) as seen in the dark area within the mycelia. Mycelial characteristics changed with increasing temperatures. At the beginning of growth, mycelium was filamentous (Figure 3 - C), while at the end of the experiment, colonies formed halos of conidia lined by undulate to lobate dirty-white mycelium margins throughout the medium, with the presence of conidia on MEA and BEAN marked by dark areas (Figure 3). On MEA, the reverse side of the colonies showed olivaceous color (Figure 3 - D); however, on V8, PDA, and BEAN this characteristic was less pronounced.

Except on V8 and at $15^{\circ} \mathrm{C}$, A. eucalyptorum showed dirty-white mycelium growing sparsely within the medium that stimulated the 
growth of fluffy aerial mycelium. The color of mycelium on Harknessia species vary and is usually fluffy (10). On MEA, H. rhabdosphaera grows by spreading through the medium, with fluffy dirty-cream mycelium, a surface color of buff to honey, with sporulation in black masses, forming dark margins (25). These margins suggest similarity to Harknessia spp. and A. eucalyptorum, but variations in color and naked conidia on hyphae formed by $A$. insueta and $A$. eucalyptorum can help to distinguish these species.

According to Lee et al. (18), mycelium of A. insueta grows within the medium and sporulates on naked hyphae in one week, while Harknessia forms conidiomata in vitro, and A. eucalyptorum has slimy sporulation on superficial mycelium, according to Crous et al. (6). Different culture media influence morphologic characteristics of fungi $(17,24)$, and such variations on different media can impede identification and distinction between species. One of the characteristics used to distinguish Harknessia spp. from Apoharknessia spp. is growth pattern and time of sporulation in vitro $(6,18)$. Thus, cultivation and characterization of in vitro colonies are important to identify these related species. Moreover, sporulation is also important as $A$. eucalyptorum differs from $A$. insueta in terms of the size of the conidia and the guttule in conidia (6).

The first test of in vitro cultivation of the pathogenic fungus $A$. eucalyptorum is presented in this study. However, there is a lack of information about its geographical distribution, inoculation methods, and potential impacts on plantations. Improving in vitro cultivation is a key step in molecular biology to understand the relation of a pathogen with different eucalypt hosts and for studies about the possible impacts of a pathogen on Eucalyptus spp. Based on these results, MEA, PDA, and BEAN are indicated for the cultivation of Apoharknessia eucalyptorum since they promoted better growth and sporulation of the species at $25^{\circ} \mathrm{C}$.

\section{ACKNOWLEDGMENTS}

The authors thank CAPES for the financial support for this research, and Klabin S.A. for the support conducting research with pathogens in Southern Brazil. We also thank Matteo Galli, Sercan Pazarlar, and Dr. Bruno César Rossini for support with DNA extractions. We are thankful to Prof. Dr. Karl-Heinz Kogel, Dr. Jafargholi Imani, and Ute Micknass for the assistance while visiting Giessen. We thank Dr. Evelyn Roberta Nimmo for editing and reviewing the English of the manuscript.

\section{REFERENCES}

1. Alfenas, R.F.; Pereira, O.L.; Freitas, R.G.; Freitas, C.S.; Dita, M.A.D.; Alfenas, A.C. Mass spore production and inoculation of Calonectria pteridis on Eucalyptus spp. under different environmental conditions. Tropical Plant Pathology, Brasília, v. 38, n. 5, p. 406-413, 2013.

2. Alfenas, A.C.; Mafia, R.G. Métodos em fitopatologia. Viçosa: Editora UFV, 2007. 382 p.

3. Auer, C.G., Santos, A.F. Doenças em eucaliptos destinados à produção de energia na região Sul do Brasil. Pesquisa Florestal Brasileira, Colombo, v. 31, n. 68 , p. 373-379, 2011.

4. Batista, K.A.; Fernandes, K.F. Development and optimization of a new cule ture media using extruded bean as nitrogen source. MethodsX, Amsterdam, v. 2, p. 154-158, 2015.

5. Basu, S.; Bose, C.; Ojha, N.; Das, N.; Das, J.; Pal, M.; Khurana. S. Evolution of bacterial and fungal growth media. Bioinformation, Puducherry, v. 11, n. 4, p. 182-184, 2015.

6. Crous, P.W.; Wingfield, M.J.; Burgess, T.I.; Hardy, G.E.St.J.; Barber, P.A.;
Alvarado, P.; Barnes, C.W.; Buchanan, P.K.; Heykoop, M.; Moreno, G.; Thangavel, R.; van der Spuy, S.; Barili, A.; Barrett, S.; Cacciola, S.O.; Cano-Lira, J.F.; Crane, C.; Decock, C.; Gibertoni, T.B.; Guarro, J.; Guevara-Suarez, M.; Hubka, V.; Kolařík, M.; Lira, C.R.S.; Ordoñez, M.E.; Padamsee, M.; Ryvarden, L.; Soares, A.M.; Stchigel, A.M.; Sutton, D.A.; Vizzini, A.; Weir, B.S.; Acharya, K.; Aloi, F.; Baseia, I.G.; Blanchette, R.A.; Bordallo, J.J.; Bratek, Z.; Butler, T.; Cano-Canals, J.; Carlavilla, J.R.; Chander, J.; Cheewangkoon, R.; Cruz, R.H.S.F.; Silva, M.; Dutta, A.K.; Ercole, E.; Escobio, V.; Esteve-Raventós, F.; Flores, J.A.; Gené, J.; Góis, J.S.; Haines, L.; Held, B.W.; Horta Jung, M.; Hosaka, K.; Jung, T.; Jurjević, Ž.; Kautman, V.; Kautmanova, I.; Kiyashko, A.A.; Kozanek, M.; Kubátová, A.; Lafourcade, M.; La Spada, F.; Latha, K.P.D.; Madrid, H.;E.F. Malysheva, E.F.; Manimohan, P.; Manjón, J.L.; Martín, M.P.; Mata, M.; Merényi, Z.; Morte, A.; Nagy, I.; Normand, A.C.; Paloi, S.; Pattison, N.; Pawłowska, J.L.; Pereira, O.L.; Petterson, M.E.; Picillo, B.; Raj, K.N.A.; Roberts, A.; Rodríguez, A.; Rodríguez-Campo, F.J.; Romański, M.; Ruszł kiewicz-Michalska, M.; Scanu, B.; Schena, L.; Semelbauer, M.; Sharma, R.; Shouche, Y.S.; Silva, V.; Staniaszek-Kik, M.; Stielow, J.B.; Tapia, C.; Taylor, P.W.J.; Toome-Heller, M.; Vabeikhokhei, J.M.C.; van Diepeningen, A.D.; Van Hoa, N.; Van Tri, M.; Wiederhold, N.P.; Wrzosek, M.; Zothanzama, J.; Groenewald, J.Z. Fungal Planet Description sheets 558-624-Apoharknessia eucalyptorum. Persoonia, Leiden, v. 38, p. 270-271, 2017.

7. Crous, P.W.; Summerell, B.A.; Shivas, R.G.; Carnegie, A.J.; Groenewald, J.Z.A. A re-appraisal of Harknessia (Diaporthales), and the introduction of Harknessiaceae fam. nov. Persoonia, Leiden, v. 28, p. 49-65, 2012a.

8. Crous, P.W.; Summerell, B.A.; Alfenas, A.C.; Edwards, J.; Pascoe, I.G.; Porter, I.J.; Groenewald, J.Z. Genera of diaporthalean coelomycetes associated with leaf spots of tree hosts. Persoonia, Leiden, v. 28, p. 66-75, 2012 b.

9. Crous, P. W.; Mohammed, C.; Glen, M.; Verkley, G.J.M.; Groenewald, J.Z. Eucalyptus microfungi known from culture 3. Eucasphaeria and Sympoventuria genera nova, and new species of Furcaspora, Harknessia, Heteroconium and Phacidiella. Fungal Diversity, Dordrecht, v. 25, p. 19-36, 2007.

10. Crous, P.W.; Wingfield, M.J.; Nag Raj, T.R. HARKNESSIA SPECIES OCCURING IN SOUTH AFRICA. Mycologia, Lancaster, v. 85, n. 1, p. 108-118, 1993.

11. Crous, P.W.; Knox-Davies, P.S.; Wingfield, M.J.A. List of Eucalyptus Leaf Fungi and their Potential Importance to South African Forestry. Suid-Afrikaanse Bosboutydskrif, Pretoria, v. 149, p. 17-29, 1989.

12. Dubey, R.C.; Maheshwari, D.K. Practical Microbiology. 7. ed. Nova Delhi: S. Chand \& Company Ltd, 2011. 397 p.

13. Farr, D.F.; Rossman, A.Y. Dwiroopa, a coelomycetous genus with two species. Mycoscience, Tokyo, v. 44, p. 443-446, 2003.

14. Food and Agricultural Organization of United Nations - FAO. Global review of forest pest and diseases. Roma: FAO. FAO Forestry Paper 156, 2009. Available at: <http://www.fao.org/3/a-i0640e.pdf>. Accessed on: 18 Apr. 2018.

15. Furlanetto, C.; Dianese, J.C. Some coelomycetes from Central Brazil, Mycological Research, Amsterdam, v. 102, n. 1, p. 19-29, 1998.

16. Garrett, A.T.A.; Imani, J.; Tambarussi, E.V.; Garcia, F.A.O.; Kogel, K.H.; Figueiredo Filho, A. First report of Apoharknessia eucalyptorum on Eucalyptus dunnii in Brazil. Forest Pathology, Aberdeen, e12463, 2018.

17. Koley, S.; Mahapatra, S.S. Evaluation of Culture Media for Growth Characa teristics of Alternaria solani, Causing Early Blight of Tomato. Journal of Plant Pathology \& Microbiology, Los Angeles, S1, p. 1-5, 2015.

18. Lee, S.; Groenewald, J.Z.; Crous, P.W. Phylogenetic reassessment of the coe elomycete genus Harknessia and its teleomorph Wuestneia (Diaporthales), and the introduction of Apoharknessia gen. nov. Studies in Mycology, Utrecht, v. 50, p. 235-252, 2004.

19. Marin-Felix, Y.; Hernández-Restrepo, M.; Wingfield, M.J.; Akulov, A.; Carnegie, A.J.; Cheewangkoon, R.; Gramaje, D.; Groenewald, J.Z.; Guarnaccia, V.; Halleen, F.; Lombard, L.; Luangsa-Ard, J.; Marincowitz, S.; Moslemi, A.; Mostert, L.; Quaedvlieg, W.; Schumacher, R.K.; Spies, C.F.J.; Thangavel, R.; Taylor, P.W.J.; Wilson, A.M.; Wingfield, B.D.; Wood A.R.; Crous, P.W. Genera of phytopathogenic fungi: GOPHY 2, Studies in Mycology, Utrecht, v. 92, 47-133, 2018.

20. Madigan, M.T.; Martinko, J.M.; Dunlap, P.V.; Clark, D.P. Microbiologia de Brock. 12 ed. Porto Alegre: Artmed, 2010. 1160 p.

21. Montilla, J.O.; Rodriguez, D. Comportamiento de cultivares de Eucalyptus urophylla S. T. Blake ante la necrosis foliar causada por Harknessia sp. Revista de la Facultad de Agronomía, Maracay, v. 20, p. 34-42, 2003.

22. Reda, F.R. Caracterização morfofisiológica e molecular, sintomatologia e 
severidade de Pestalotiopsis spp. STEYAERT em mudas de Eucalyptus dunnii MAIDEN. 2017. 63 f. Dissertação (Mestrado em Ciências Florestais). Universidade Estadual do Centro-Oeste, Irati.

23. Ruperez, A.; Muñoz, C. Enfermedades de los eucaliptos en España. Boletín de sanidad vegetal. Boletín de Sanidad Vegetal - Plagas, Logroño, v. 6, p. $193-217,1980$.

24. Sharma, G.; Pandey R.R. Influence of culture media on growth, colony character and sporulation of fungi isolated from decaying vegetable wastes. Journal of Yeast and Fungal Research, Nairobi, v. 1, n. 8, p. 157-164, 2010.

25. Summerell, B.A.; Groenewald, J.Z.; Carnegie, A.; Summerell, R.C.; Crous, P.W. Eucalyptus microfungi known from culture. 2. Alysidiella, Fusculina and Phlogicylindrium genera nova, with notes on some other poorly known taxa. Fungal Diversity, Dordrecht, v. 23, p. 323-350, 2006.

26. Su, Y-Y.; Qi, Y-L.; Cai, L. Induction of sporulation in plant pathogenic fungi. Mycology, London, v. 3, n. 3, p. 195-200, 2012.

27. Swart, H.J. AUSTRALIAN LEAF-INHABITING FUNGI III. OBSERVATIONS ON HARKNESSIA. Transactions of the British Mycological Society, London, v. 59, n. 2, p. 309- 311, 1972.

28. Yuan, Z.; Wardlaw, T.; Mohammed, C. Harknessia species occurring on eucalypt leaves in Tasmania, Australia. Mycological Research, Amsterdam, v. 104, n. 7, p. 888-892, 2000.

29. Yuan, Z.; Mohammed, C. Investigation of fungi associated with stem cankers of eucalypts in Tasmania, Australia. Australasian Plant Pathology, Berlin, v. 26, p. 78-84, 1997. 